\title{
RELATIONAL INVESTING: THE WORKER'S PERSPECTIVE
}

Edward P. Lazear

Richard B. Freeman

Working Paper 5436

\author{
NATIONAL BUREAU OF ECONOMIC RESEARCH \\ 1050 Massachusetts Avenue \\ Cambridge, MA 02138 \\ January 1996
}

This work was supported in part by the National Science Foundation. This paper is part of NBER's research program in Labor Studies. Any opinions expressed are those of the authors and not those of the National Bureau of Economic Research.

(C) 1996 by Edward P. Lazear and Richard B. Freeman. All rights reserved. Short sections of text, not to exceed two paragraphs, may be quoted without explicit permission provided that full credit, including $(\mathcal{O}$ notice, is given to the source. 


\title{
RELATIONAL INVESTING: THE \\ WORKER'S PERSPECTIVE
}

\begin{abstract}
Workers who hold a firm's stock make decisions other than those that pure capital owners would make, but there exist institutions and compensation packages that will generally lead workers to favor efficient firm decisions. Workers care about their firm-specific rents and may seek shares in their firm to use them to protect those rents. Their views toward firm decisions will differ depending on their firm-specific human capital and tenure in the firm. The workers most favorable to efficient firm decisions are the very young and very old, who have the least amount to lose in employment rent and those with larger shares of ownership. An appropriate severance pay policy will induce workers to choose efficient outcomes even if it calls for their own layoffs. Single company based defined contribution pension funds, which hold shares in their own firm, are likely to tilt worker-owners to favor efficient decisions when layoffs and other changes are modest, but not when the changes are huge. Pension funds are more likely to buy up shares and successfully change behavior in small firms, in firms that are highly levered, and when the investment community has diverse views on the benefit from changing a firm's current irresponsible policies.
\end{abstract}

Edward P. Lazear

Graduate School of Business

Stanford University

Stanford, CA 94305-5015

and NBER
Richard B. Freeman

Department of Economics

Harvard University

Cambridge, MA 02138

and NBER 
Workers can affect decisions that corporations make in a variety of ways. As individuals, workers can vary their effort in response to wages and working conditions offered by the firm. Collectively, workers can form trade unions to bargain with management over wages and work rules and establish grievance rights on the interpretation of contracts. In Europe, most countries mandate works councils that have information and consultation rights at their work sites. Germany gives councils co-determination rights over some personnel decisions as well (Freeman and Lazear, 1994). Canada mandates works councils for occupational health and safety and obligates nonunion management to find representative workers for those councils. These "normal" ways for workers to influence company decisions are widely studied.

There exist more novel ways by which labor can voice its opinion and influence company decisions. In Germany, workers have an equal number of seats on the boards of directors (the "supervisory board" under the Co-Determination Act of 1976) with capital owners, giving them potential influence on broad corporate decisions. But the chairman of the supervisory board, a representative of capital owners, has the deciding vote (Hans Bockler Foundation). The folklore about worker participation and consensual decision-making in Japanese firms permeates all aspects of business writing ${ }^{1}$. In the United States, ESOPs and pension plans invest in the employees' company. This gives workers ownership as well as employee interest in company decisions and a potential tool for influencing those decisions. Since Peter Drucker's 1976 book on pension fund capitalism, the pension fund share of the capital market has aroused immense commentary (Randy Barber and Jeremy Rifkind, George Borjas). The recent activist policies of California public employees pension 
fund, CALPERS, show that pension funds can influence management decisions. Finally, workers' ownership of firms, while limited, has also been growing. The recent purchase of United Airlines by its workers is an important example.

All told, as collective bargaining has declined in the American private sector, the number of workers who can exercise voice in novel ways on company decisions has grown. For 1989, Blasi and Kruse (1991) estimated that 10.8 million workers were employeeowners, either in ESOPS or related plans, which exceeded the 10.5 million private sector union members. The National Center for Employee Ownership estimates that the number of employee-owners rose to 15 million in 1995, while union membership fell (private communication). As a result there are roughly $50 \%$ more workers with the possibility of influencing firm decisions as partial owners than with the possibility of influencing decisions through collective bargaining.

How might employee share ownership affect corporate decisions? Will workers push companies in ways that differ from those made by owners with no employment at the enterprise? Which worker characteristics are likely to be important in determining the worker's viewpoint? Does the worker as pension fund owner have different interests than the worker as active employee? How does ownership affect worker incentives? Is a more active role by labor in corporate governance likely to help or hinder the performance of the firm?

This paper explores labor's potential role in corporate governance from the perspective of standard economic theory. While this theory does not always accurately behavior, at the minimum it provides a measuring rod or benchmark for considering more 
complex behavior -- a starting point for analysis.

The paper makes three basic claims:

1) Increasing worker ownership can increase worker support for efficient firm policies, even on such a potentially divisive topic as layoffs.

2) Workers' are likely to differ in their views of firm policy depending on their age or years of service in a non-monotonic way. The interests of the young and old are such that they may team up against the middle aged in some areas.

3) Worker's desire to protect their specific human capital is an important reason for them to own stock in their own company. This point runs counter to the usual diversification argument against holding assets in their own firm.

\section{The Decision of Workers}

If workers had greater say in company decision-making, would they make decisions that are in the best interest of the "firm"?

The answer depends on the breadth of definition of the firm. We define the firm as a social unit whose value is the joint return to labor and capital, taking into account the opportunity costs to each side. It is appropriate to think in terms of the joint social output for two reasons. First, since one of the main issues is determining ownership, it is erroneous to start with any stakeholder's interests in mind. Second, maximizing joint return is equivalent to maximizing profits in an ideal competitive market with free entry. When human and physical capital is general and transactions costs are small, the decisions of a particular firm have little impact on capital or labor. Resources move smoothly to their next best opportunity. 
Co-determination in decision-making is important only when there is relation specific capital. Investments in firm-specific capital by workers or by the firm alter the incentives to keep the relationship intact. For example, if workers receive more at their current firm than they could earn elsewhere, they suffer a loss on separation and may resist layoffs. The specificity of the relation gives employees an interest in company decisions that they would not have if their next best opportunity offered the same rewards. Some firm decisions may benefit capital at the expense of labor. Layoffs can fit this category, as can the introduction of labor-saving technology that costs jobs, or development of plants in low-wage competitive locations. Other decisions may benefit both sides. A good marketing campaign that raises sales will benefit employees as well as capital. A major investment program that creates additional jobs and sales will do the same.

Finally, whether workers make decisions that are in the best interest of the "firm" or not depends on the extent of worker ownership. Increases in worker ownership will give them greater influence on decisions, moving those decisions toward labor against non-labor owners of capital. But it will also increase the overlap of interest between workers and capital: an employee with substantial shares in a firm will be more attuned to the interests of capital than one with no ownership. Since workers of different ages or tenure usually have different employee and ownership stakes in a firm, we expect them to have differing interests.

Since worker interests in firm decisions are fostered by their having relation specific capital, we assume such a relation in the remainder of this essay ${ }^{2}$. We examine worker interest in separate firm decisions and likely differences in the interests of workers of 
different ages.

\section{Layoff Policy}

Consider first how workers with some ownership stake in a firm might want to influence firm policies on layoffs. Layoffs are a prototype for any decision that might break the employment contract and potentially harm labor with firm-specific capital. It is the archetype case where the interests of workers are likely to differ from those of other owners.

Suppose that a firm employs $L^{*}$ workers and that labor owns $\lambda$ of the firm, with $(1-\lambda)$ being held by non-labor interests. Assume that the demand for labor falls so that taking into account the opportunity cost of workers, the socially efficient level of employment drops from L* to L'. How will workers with a share in the firm view this decision? Layoffs help labor-as-owner by increasing the value of the firm. But layoffs hurt labor-as-worker by forcing some to take another job, potentially below the current wage.

The workers with firm specific human capital share the costs and benefits of such investments with the firm. Their age-earnings and age-productivity profiles are shown in the top panel of figure 1. Workers earn $W(t)$ at the current firm compared to $A(t)$ at another firm. Productivity at the firm is $V(t)$. For expositional convenience, the interest rate is taken to be zero in the diagram. The bottom panel of figure 1 plots economic quasi-rent as a function of age. There are two measures of rent. First, since the worker shares in the costs and benefits from the investment in specific human capital, define the worker's rent as

$$
e^{r t} \int_{\tau}^{T}[W(Y)-A(\gamma)] e^{-r \tau} d \gamma
$$


where $\mathbf{r}$ is the rate of interest, assumed zero in the diagram. The rent that goes to the firm is given by

$$
e^{r t} \int_{\tau}^{T}[V(\tau)-W(\tau)) e^{-r \tau} d \tau
$$

and total rent is merely the sum of $R_{w}+R_{f}=R$, given by

$$
e^{r t} \int_{\tau}^{T}[V(\gamma)-A(\gamma)] e^{-r t} d \gamma
$$

Workers range in age from 0 to $\mathrm{T}$, and thus are in different parts of their age-earnings investment and return life. An efficient layoff rule lays off workers from both ends of the age spectrum. The least total rent is lost by laying off workers who have invested little in firm-specific capital or those who are close to retirement. If there is a permanent decline in demand for the product, which shifts $V(\tau)$ down, there is a new $V(\tau)$ curve as $\beta V(\tau)$ in figure 1. Under these new circumstances, employees who were previously efficient to employ should not be working. All the individuals between $t_{y}$ and $t_{m}$ are still sufficiently productive relative to their alternatives to remain employed. All those younger than $t_{y}$ and those older than $t_{m}$ are not sufficiently productive to be efficiently employed. The value of their alternatives exceeds the value of their output. The fact that output is now worth $\beta V(\tau)$ implies that total rent shifts from $R(\tau)$ to $\hat{R}(\tau)$. All those with $\hat{R}(\tau)<0$ should leave the 
firm. Put differently, all those whose total rent, $R(\tau)$, before the demand shock was below

$R^{*}$ should now work elsewhere because their social value is higher elsewhere.

Will workers as shareholders vote for an efficient layoff policy? All workers between ages $t_{y}$ and $t_{m}$ favor the layoffs. They lose nothing by an efficient layoff policy and gain through appreciation of their stock ${ }^{1}$. But young workers and old workers certain to be laid off should oppose the layoff policy if they lose more in rent than they gain in stock appreciation. A worker who is to be laid off votes for the layoff iff

(4) $\quad R_{w}(t)<\frac{\lambda \Delta K}{L^{*}}$

The r.h.s. is the worker's capital gain from an efficient layoff policy. There are $L^{*}$ workers, each of whom has an equal stake in the firm. Since $\lambda$ is the proportion of the firm owned by labor, the r.h.s. is each worker's individual capital gain.

A worker subject to layoff will vote for an efficient layoff policy if his losses in employee rent are small relative to his capital gain on the stock he owns. This implies:

1. In the absence of firm specific human capital, workers favor an efficient layoff policy. At the extreme, when there is nothing firm specific and when mobility costs are zero, $R_{w}=0 \forall t$. Absent rents at the firm, all workers care about is that the firm maximize capital value. An efficient layoff policy raises the value of the firm and thereby the wealth

${ }^{1}$ It is assumed that the layoff is a once and for all policy. Otherwise workers who are close to the layoff cutoff ages might fear that they will be the first ones let go in subsequent layoffs, inducing them to vote against this layoff. 
of share-holding workers. 2. The larger the ownership stake that labor has, the more likely workers are to vote for the layoff, because this increases the value of the capital gains.

If $\lambda=0$ so that workers have no ownership, they do not favor efficient layoffs, but they cannot vote. If $\lambda=1$ so that workers own the entire firm, then workers not targeted for layoff vote for efficient layoff, and those who will be laid off are most likely (as compared with any other $\lambda$ ) to vote for layoff. But if $\lambda=1$, then the firm goes as labor decides. Non-labor stakeholders (for instance, owners of non-voting shares of stock or holders of bonds or creditors) would prefer the efficient layoff policy so making labor the full owner of the firm diminishes the votes for an efficient layoff policy.

Intermediate cases are more complicated. There are two competing factors: the effect of "no" votes from workers replacing "yes" votes from non-labor shareholders versus the reduction of worker opposition to this policy as their ownership stake rises.

A numerical example highlights the divergence of interest among workers. Suppose that a firm employs 100 workers who have a $5 \%$ share of the firm. Increasing labor's ownership stake to, say, $10 \%$ could increase the number of votes for an efficient layoff policy. To see this, assume the rent function has a simple parabolic relation to the age of workers: $R_{w}(t)=$ $.1 \mathrm{t}-.0025 \mathrm{t}^{2}$ and that the distribution of workers is uniform across ages between 0 and 40 . Suppose that the efficient layoff policy requires that workers with prior rent, $\boldsymbol{R}_{W}$, less than .9 be laid off, i.e., all except those between $t=13.68$ and 26.32 in figure 2 . This implies that $68.4 \%$ of the workers in the firm be laid off and just $31.6 \%$ protected. If workers have $5 \%$ of the shares then $.316 \times .05$ are sure to vote for the efficient layoff, since they are 
protected. This amounts to .0158 of the shares. These workers gain through the capital gains on their stock by an efficient layoff policy.

The rest of the workers decide according to (4) whether the capital gains from the layoff exceed the rent losses from changed employment. Suppose that the change in the value of the firm, $\Delta \mathrm{K}$, is 900 . Since workers own $5 \%$, each worker earns a capital gain of .45 from efficient layoffs. Workers younger than 5.17 or older than 34.83 prefer the layoff and vote yes. But those between 5.17 and 13.68, as well as those between 26.32 and 34.83 oppose the layoff since the rents they lose from the layoff exceed their capital gains. In figure 2, this group has $R_{w}>.45$. Given the uniform distribution of ages, $43 \%$ of the workers vote against the layoff, and $57 \%$ vote in favor. In terms of shares, since workers have $5 \%$ of the stock, $2.13 \%$ of the stock votes no and the remaining $2.87 \%$ belonging to workers votes yes.

Now, increase the worker's share to $10 \%$ of the stock, so that each worker owns .001 of the firm. A capital gain of 900 from efficient layoffs translates into a capital gain of .9 per worker. Now every worker would vote for the efficient layoff. Those younger than 26.32, but older than 13.68, are not laid off and all the others have labor rent less than .9 . Both groups prefer the efficient layoff policy.

Thus, when $5 \%$ is held by the workforce, $2.13 \%$ votes no. When $10 \%$ is held by the work force, $0 \%$ votes no. Increasing the number of shares held by workers increases the proportion of shares voting for the efficient layoff policy. When many workers are close to voting yes, giving a larger fraction of the capital gains to workers pushes all workers over the margin. 
3. Of the laid off workers, those closest in age to either $t_{y}$ or $t_{m}$ are likely to oppose the layoff since $R_{w}$ declines as $t$ goes to 0 or $T$. Workers who just miss the no layoff cutoff are most upset about being laid off. Those who have just started with the firm or are about to retire put up the least resistance.

This creates an unusual alliance among workers. The oldest and youngest side with the middle aged against those on opposite sides of each cutoff. In figure 1, the workers who most dislike the efficient layoff policy are those who are slightly younger than $t_{0}$ or slightly older than $t_{1}$. But those slightly older than $t_{0}$ and those slightly younger than $t_{1}$ are strongly in favor of the efficient layoff policy. The latter group is not targeted for layoff and enjoys the capital gains associated with the efficient layoff policy. Thus, a firm might find that the workers between 35 and 55 years of age favor the layoff policy (because they will not be laid off); whereas those between 25 and 30 and those between 60 and 65 favor it because the employment rent lost through layoff is smaller than their capital gains on stock. But those between 30 and 35 and those between 55 and 60 oppose the efficient layoffs. They are targeted for layoff and have quite a bit of employment rent to lose.

4. For any given capital gain, the proportion of workers who vote against the layoff increases with the size of the reduction-in-force. Recall that there are two reasons for voting in favor of a layoff. Some workers (the middle age ones) are protected from layoff. Others who are laid off workers do not lose much because they recently started with or are soon to retire from the firm. The size of this second group, which favors layoffs because capital gains exceed labor rent, does not depend on the depth of layoffs. Its age bounds are set such that the 1.h.s. of (4) equals the r.h.s. of (4). This is independent of the number of layoffs. 
But the size of the first group depends on the depth of the cuts. For example, if all workers were laid off, the group of unaffected workers would have no members. There would be no protected workers. Then, the only workers who would favor the layoff would be those whose capital gains exceed employment rents. In the example illustrated in figure 2, increasing the depth of the layoff moves the boundaries at 13.68 and 26.32 toward the center of the diagram. If all workers were to be laid off, the range of protected workers would be degenerate with no workers in the group. The basic point of this analysis is that workers who have shares in their own organization do not vote as a block. Their interests vary depending on their age and amount of firm specific human capital. Even when it comes to layoffs, workers divide depending on their age or years of service to the firm. Nor is the division monotonic. The young and old may team up with the middle aged against those in their $30 \mathrm{~s}$ and $50 \mathrm{~s}$.

\section{Seniority Based Layoffs with Buyout Provisions}

The layoff rule described above deviates from the common American practice of basing layoffs on reverse seniority. Indeed, under U.S. law, laying off old workers probably violates the Age Discrimination in Employment Act, which protects workers who are 40 and older.

One scheme frequently used by firms that reduce employment is to buyout senior workers by offering them the option to stay or leave at some price. A firm that adopted an efficient layoff policy and coupled it with a buyout scheme could induce most workers to favor the plan. Under these circumstances, all worker held shares would vote for the efficient layoff plan. 
Efficiency requires that workers leave after a demand shock when the present value of marginal product at the current firm is less than the present value elsewhere ${ }^{2}$. A worker of age $t$ should leave, therefore, when

(5) $\tilde{R}(t)<0$, or equivalently, when $R(t)<R^{*}$

As before, the worker should leave when total rent, which includes the firm component is negative ${ }^{3}$. The worker cares only about $\tilde{R}_{W}(t)$, and the efficient severance pay package must remedy this. ${ }^{4}$

There several schemes that are consistent with reverse seniority layoffs and efficiency. We provide one that is efficient and does not violate age discrimination law.

First, efficiency requires that workers younger than $t_{y}{ }^{*}$ and those older than $t_{m}{ }^{*}$ be laid off. Seniority rules make it easy to accomplish layoffs of young workers. But older workers cannot be laid off without their permission. Thus, let the firm offer

$$
S=e^{r_{*}^{*}} \int_{t_{=}^{*}}^{T}[W(\gamma)-\beta V(\gamma)] e^{-\pi} d \gamma
$$

${ }^{2}$ We consider only the decision to leave now or to stay until the retirement date, $T$. It is possible that a worker should remain with the firm for some period of time and leave before $T$. We ignore these possibilities for analytic simplicity.

${ }^{3}$ Before, a demand shift was considered which meant that the rent function shifted downward from $R(t)$ to $R(t)$.

${ }^{4}$ See Lazear(1984), "Pensions and Severance Pay". 
as a buyout to all workers older, say, than $t=20$.

A worker leaves the firm if $\tilde{R}_{w}(t)<S$ or if

$$
e^{r t} \int_{t}^{T}[W(\gamma)-A(\gamma)] e^{-r \tau} d \gamma-e^{r_{i}^{*}} \int_{t_{i}^{*}}^{T}[W(\gamma)-\beta V(\gamma)] e^{-\pi} d \gamma<0
$$

For workers of age $t_{m}^{*}$, the 1.h.s. of $(7)$ is zero. For workers older than $t_{m}^{*}$, the 1.h.s. of (7) is negative since $\tilde{R}_{W}$ is decreasing in $t$ for $t>t_{m}{ }^{*}$. The 1.h.s. of (7) is positive for all workers between 20 and $t_{m}{ }^{*}$ so they do not leave. Young workers can be induced to leave the firm voluntarily, but strict layoffs are permitted for them so the firm need not provide severance pay to workers younger than $t_{y}^{*}$.

Who would favor efficient layoffs given this severance pay rule? All those who are not targeted for layoffs prefer efficient layoffs. Also, the old workers who leave voluntarily prefer efficient layoffs since their payment exceeds the rent that they receive from staying, even without the capital gain on stock. The capital gains make them more favorable to efficiency.

Workers younger than $t_{y}^{*}$ may or may not prefer the efficient layoff policy. Without severance pay, this depends on (4). But there is a severance payment that can make even reluctant members of this group prefer efficient layoffs. Suppose that $S_{y}$ is defined as the severance pay given to workers who are $t_{y}^{*}$ or younger. (It is important that it not be offered to workers older than $t_{y^{*}}$ or some may take it inefficiently.) If $S_{y}$ is set such that 
(8)

$$
S_{y}=e^{\tau t ;} \int_{t_{j}^{*}}^{T}[W(\tau)-A(\tau)] e^{-r t} d \tau-\frac{\lambda \Delta K}{L^{*}}
$$

holds, then all workers $t_{y} *$ and younger will prefer efficient layoff to working at the current firm without an efficient layoff policy. If the efficient layoff policy is adopted, workers of age $t_{y} *$ are laid off and receive

$$
e^{\pi_{y}^{*}} \int_{\xi_{y}^{*}}^{T} A(\gamma) e^{-r} d \gamma+S_{y}+\frac{\lambda \Delta K}{L^{*}}
$$

or

$$
\int_{t_{r}^{*}}^{T} w(\gamma) e^{-\pi} d \gamma
$$

If an efficient policy is not adopted, these workers receive their wage until retirement, i.e., the same amount. So with severance pay $S_{y}$, workers of age $t_{y}$ are indifferent between policies; while those younger than $t_{y}^{*}$ prefer efficient layoffs with severance pay.

We conclude that workers with shares in an organization may support an efficient layoff process. As long as management sets up the appropriate golden parachute, workers can be induced to favor an efficient layoff policy. Moreover, the golden parachute need not alter the distribution of rents between capital and labor. This is because the firm can alter 
the shape of the age-earnings profile to keep the share of rents the same. During the early years in the firm, wages are reduced to cover the expected cost of the severance pay policy. The reduction in wages is equivalent to an "insurance premium" paid by workers for which they receive severance pay if conditions in the industry turn sour. Workers are no worse off in terms of their total (expected) labor earnings and they are better off in terms of the value of their capital. The steeper age-earnings profile, coupled with golden parachutes for workers, results in better outcomes. This scheme sets up a mechanism under which workers as shareholders vote for efficient layoff schemes. Every worker and every shareholder is better off as a result.

The models in this section have an important general bottom line conclusion: different ownership practices are compatible with economic efficiency, as long as the firm is artful in choosing its compensation package.

\section{Do Capital and Management Behave Appropriately?}

When workers invest in firm specific human capital, non-labor owners have an incentive to renege on their contracts with labor by not taking labor's lost rent into account in its decisions. Formally, since $R_{f}(t)<R(t)$, myopic capital owners will be too willing to lay workers off.

There is one potential offset to this: the loss of the firms' reputation as an employer, which may make hiring sufficiently difficult in the future, as to make a quick layoff policy nonprofitable. Indeed, if reputation were perfect, the efficient employment policy would dominate other strategies and non-labor owners would only lose by laying off workers inefficiently. Layoffs would occur but only when the value of the layoff exceeded the cost. 
With perfect reputation, all layoffs desired by non-labor owners are efficient.

The assumption that reputation is perfect is a strong one. An alternative that might yield the same efficient outcome would be if a previously successful firm would go out of business next period absent labor concessions. In this case, the firm has every incentive to take only $R_{f}$ into account and ignore $R_{w}$. Workers would have the same incentive, to accept lower wages and save their jobs if they had the same information and found it believable (Freeman and Lazear, 1995).

Still, there are two differences between non-labor owners of capital and labor. First, since the value of the firm's decisions are reflected in the stock price, the time horizon of capital should be long. Non-labor shareholders want to maximize the capital value of the firm. Second, in principle shareholders should be of one mind. If shareholders do not agree with the current policy of the firm, they can sell their shares and move their assets into another form ${ }^{5}$. Workers live finite lives and cannot sell their human capital to the next generation. As a result, their views about employment depend heavily on age. As already discussed, workers may have different views on layoff policy and their resistance to layoffs is not monotonically related to age.

\section{Non-Labor Owners' Desire For Worker Ownership}

In the absence of ownership, workers have only conventional labor conflict tools to influence managerial decision. They can make demands and back them up by withholding labor, either through a strike or some other form of industrial non-compliance. Stock ownership gives

${ }^{5}$ Work by Bagwell and Judd (1988) suggests that there may be significant differences of opinion among capital owners. If nothing else, capital gains taxes prevent owners from selling at the slightest disagreement with management. 
workers another channel through which they can affect decisions. While proxy battles are rare, they do occur. The threat of a proxy fight provides labor as owners with another way to affect policy. For this reason, non-labor owners may want labor to have a stake in the firm, but not too large a stake. To see this consider the following example. Suppose that a firm anticipates one more year of operation at the current scale and then will shut down altogether. The division of rent between capital and labor is subject to negotiation. As before, $A(\tau)$ gives the reservation wage of each worker and $\mathrm{V}(\tau)$ is the amount that the worker is worth to the firm. While $\mathrm{W}(\tau)$ was the wage path before news of the firm's problems hit, now management would like to revert to an end-game strategy of paying each worker $A(\tau)$.

In the absence of ownership, labor can either accept the wage of $A(\tau)$ or strike. If $W(\tau)$ were just slightly above $A(\tau)$, the threat to strike might not be credible. A strike implies that the full value of $W(\tau)$ is lost as an investment in securing $W(\tau)-A(\tau)$ during the subsequent year. Instead of striking, workers might just accept a wage reduction. The cost of accepting the reduced wage is

(9) Cost of accepting wage reduction $=\int_{0}^{1}[W(\gamma)-A(\gamma)] e^{-r} d \gamma$

which is small for workers whose wage is close to their alternative wage. It might be difficult for a union to generate a positive strike vote over this issue, especially when it is known that the firm will fold in a year. Thus, the treat to strike is not credible.

Suppose instead, however, that labor had a significant fraction of the shares in the organization. A move to reduce labor's wages to $A(\tau)$ could be resisted through proxy battles, 
which impose no direct cost to labor. The mere threat of such a battle might prevent non-labor owners from attempting to reduce workers' wages in these circumstances. ${ }^{6}$ Because workers know that they have the proxy battle as an additional instrument, they also know that they will be in a strong position should the firm decide to fold. This increases labor's willingness to invest in firm specific capital and to take other actions that might benefit non-labor owners. As a result, non-labor owners might favor some worker ownership in order to align interests of all parties.

\section{Diversification}

Conventional wisdom holds that risk averse workers should not own stock in their own organization. Since worker's firm-specific human capital is tied closely to the fortunes of the firm, workers should not invest in the firm's physical capital, since its returns will be highly correlated with their human capital. This ignores the effect that ownership has on worker behavior and on firm decisions. Our analysis suggests that the desire by workers to protect their firm specific human capital is greatest when they have large amounts. This is true even when diversification arguments push strongly in the direction of holding physical assets whose returns are negatively correlated with those in the worker's own firm. In cases when risk aversion would suggest investing elsewhere the worker might want the most control over his own organization, because their quasi-rents are large.

\section{Incentive Effects of Stock Ownership}

\footnotetext{
${ }^{6}$ Heterogeneity of preferences among shareholders might be helpful to labor. If workers can combine their shares with a sub-set of other owners, a deal may be struck whereby labor maintains its wage and the other owners obtain what they want, even if labor's share is relatively small.
} 
An often touted benefit of worker ownership is that ownership generates positive incentives. But the existence of profit sharing, either directly through compensation, or indirectly through stock ownership, may have little effect on worker incentives because free rider effects are too strong (Kandel and Lazear (1992)). In an organization of any size, the effect of an individual's effort on personal compensation is trivial since most of the gains go to other owners.

Profit sharing is useful primarily when workers empathize with other workers to a greater extent than with non-labor owners of capital. Since reduced effort harms owners, stock ownership is a motivator when a worker feels worse about harming co-workers than about harming capital. In part, peer monitoring can bring this feeling about, but a worker who catches a peer shirking has little incentive to impose sanctions on the slothful worker. The punisher bears the cost of doling out punishment, but reaps only a small part of the gain.

It is for these reasons that profit sharing has only modest positive effects on productivity (Martin Weitzman and Doug Kruse (1990)). Such effects appear more likely when they are coupled with other institutional innovations that increase worker participation in enterprise decisions (see Alan Blinder; Lawrence Mishel and Paula Voos). By itself, profit-sharing will have powerful effects only on small organizations. Peer pressure, which comes about in the presence of worker ownership, works in the direction of increasing effort, but the magnitude of the effect is likely to be small in large organizations unless it is concentrated in small groups.

\section{Pension Funds}

Thus, far we have focused on situations in which individual workers vote shares in a 
firm. But in fact, the major way by which workers' share ownership is expressed is through pension funds.

A pension fund is likely to have a longer time horizon than do individual workers. The pension fund that should behave most like non-labor owners is one concerned only about the capital value of the firm. For example, consider a pension fund that operates as a mutual fund. Workers buy shares in the fund and are paid dividends on the basis of the fund's performance. The workers can sell their pension shares upon retirement or separation from the firm. This approximates the structure of some defined contribution pension funds, e.g., TIAA-CREF. Owners of TIAA-CREF come from many schools and the funds of TIAA-CREF are invested in firms other than those which employ the workers.

More interesting from our perspective are funds that invest in the firm in which future pensioners work: defined contribution company pension funds. Suppose that there was one firm and that all subscribers to the CREF-like pension fund were employed (at some time) by that firm and that shares in the firm were publicly traded. A large company might establish an independent body to administer a defined contribution pension plan for its employees. The plan would sell shares to the firm's employees and would invest the interest.

If the plan merely holds $\lambda$ of the firm, then the same issues that arose in earlier sections arise here. The fund should vote its shares, say, for an efficient layoff policy when the plan's owners benefit more from the capital gains than they lose in employment rents. But the owners comprise a large and heterogeneous group. A political structure within the pension fund must translate the different preferences of individual workers into a behavior rule for the pension fund. The simplest political analysis posits median voter decisions. Since the pension 
fund votes its shares as a block, this uniformity should give labor a larger effect on the outcome of elections. ${ }^{7}$ It is possible that the pension fund will produce greater support for an efficient layoff policy than would workers-as-owners who hold shares individually. Return to our numerical example of the efficient layoff policy. When workers as individuals held $5 \%$ of the firm's shares, $2.87 \%$ of the shares voted for efficient layoff and $2.13 \%$ voted against. But an efficient layoff policy benefits more than $50 \%$ of the workers. If the median voter controlled the pension fund's decision then the pension fund would vote all of its shares for the efficient layoff. Thus, with pension fund ownership, all $5 \%$ vote for and no worker shares vote against efficient layoff. With individual worker ownership, $2.13 \%$ vote against efficient layoff. The political mechanism of the pension fund has prevented the voices of recalcitrant workers from being heard, rather than amplifying their minority views. But if workers holding more than $50 \%$ of shares in the pension fund opposed the layoff, all pension fund shares would vote against efficient layoff, whereas individual worker ownership would usually have some workers voting for efficient layoff.

Which situation is most likely to prevail? The question is equivalent to asking whether socially beneficial views are likely to be in the majority or minority among the work force. Consider direct transfers from capital to labor, say, in the example where the firm is certain to close next year. As individuals, workers would vote $100 \%$ to transfer resources from non-labor owners to labor. The pension fund, representing the median worker, would vote the same way.

\footnotetext{
'Since pension fund managers are usually hired rather than elected from the rank-andfile, the views of the hired fund manager are likely to be similar to those of the median voter. This distinguishes the operation of the fund from that of worker elected union leader or works council. Leaders are part of the rank-and-file and as shown in Freeman and Lazear (1994), they are not necessarily a representative group.
} 
Thus, there is no difference in behavior in the case of transfers. ${ }^{8}$

In the case of minor layoffs, the pension fund will behave more responsibly than the workers as individuals. The median worker will benefit by efficient layoffs when reductions are relatively small. But when layoffs affect a majority of the work force, are efficient, the median worker is likely to resist. Then the pension fund will swing its entire weight against the layoff. If workers voted their interest individually, some would support the layoff policy. ${ }^{9}$

The conclusion is that defined contribution company based pension funds will tend to be more radical than their underlying constituency on company policies that affect a large majority of workers. But for most moves, which are more moderate in nature, the pension fund will act more responsibly than workers would if they voted their shares as individuals.

Another point distinguishes pension funds from individual workers as constituents. The pension fund operates within fiduciary legal constraints that prevent it from making certain kinds of investments. Pension funds are required to invest in ways that protect the solvency of the funds. Our analysis shows that if the solvency of the fund comes at the expense of the work force, this is not only undesirable, but prevents the pension fund from making appropriate investments. For example, a pension fund might have information about the firm in which its workers are employed that outside investors do not have. An investment by the fund in the firm might prevent an inefficient bankruptcy, but the fund might be precluded from making the

\footnotetext{
${ }^{8}$ The distribution of transfers among workers might differ in the two cases, however.
}

${ }^{9}$ Note that more than a majority of the workers must face layoffs. There is always some fraction of laid off workers who prefer the efficient layoff policy because the capital gains they receive exceed their employment rent loss. 
investment because of the inherent risk. If the investment is not made, then the firm closes and workers lose their jobs, suffering a loss of employment rent. By extension, a pension fund might vote in a way that maximizes the expected total return for workers, including their employment rent, but this might not comply with risk requirements of the fund. Such votes would be efficient but may cause managers of the pension fund to be subject to subsequent action if a negative outcome occurs. ${ }^{10}$ A union pension fund in the construction trades might prefer to invest in a lower return union construction project than in some higher return alternative. Because union workers are paid a premium, they want to keep their jobs in construction. Even if there were a lower return on pension fund support of the union contractor, this may be more than offset by the increased rent going to union workers, making the seemingly poor investment a good one from the workers' point of view.

Many workers are covered by defined contribution pension funds. A fund of this sort would not have any particular interest in any one firm since any one firm's workforce makes up a small part of the total fund owners. If the workers whose pensions were held in the fund were drawn from a particular industry, then the pension fund might conceivably have an interest in affecting outcomes. But the fund's activity would most likely be directed toward government so as to have an impact on the entire industry. While it is possible that some of these activities might be directed primarily to worker issues, for example, changing mining safety standards, many might be directed at protecting the industry. Thus, pension funds that represented workers in Silicon Valley might lobby Congress for protection from Japanese chip manufacturers. This activity might be socially undesirable, but it is likely to be in the interests of non-labor owners

\footnotetext{
${ }^{10}$ The point is best articulated in Fischel (1984).
} 
as well as labor owners of the firms in the industry.

Some pension funds use their shares to push desired social causes or to get involved in company management in other ways. They can do this by refusing to hold the shares of firms that do not adopt their own political posture. Alternatively, they can acquire positions in firms that do not behave appropriately and can attempt to change the firm's behavior ${ }^{11}$. Both strategies can be analyzed in the same way. ${ }^{12}$

Can the refusal by large funds to hold shares in a company affect that firm's ability to raise capital? The following analysis provides an answer.

Let the rate of return on capital be r. Suppose that, but for the firm's social behavior, the supply of investment dollars for its stock would be perfectly elastic up to $\mathrm{J}$ dollars at rate $r$ and perfectly inelastic thereafter. Suppose further that the pension fund assumes that it cannot affect the behavior of firms and its only choice is to hold or not to hold stock in a given firm.

A pension fund has a taste against a particular firm's policy if it must be paid $\varrho=r+h$ to be willing to hold the firm's stock. The larger is $h$, the stronger is the fund's distaste for the firm's social position. All the pension fund investment dollars have the $h$ of the fund's median voter. The taste parameter $h$ is distributed across the population of investor dollars and its density is given by $f(h)$. It is conceivable that some investors may have a negative $h$. For example, some investors might have believed that doing business in South Africa under apartheid

11 See Murphy and Van Nuys (1994) for an empirical analysis of state v. private pension funds and their investment behavior.

\footnotetext{
${ }^{12}$ This is merely an application of Becker's (1957) theory of discrimination.
} 
was a good thing, even if the vast majority disagreed.

At any rate $\varrho$, an investment dollar prefers this firm to others iff

$$
\varrho>r+h \text { or iff } \varrho-r>=h \text {. }
$$

Thus, the number of investment dollars that can be attracted by the firm at any rate $\varrho$ is

$$
\mathrm{q}_{\mathrm{s}}=\mathrm{J} \mathbf{F}(\varrho-\mathrm{r}) \text {. }
$$

As $\varrho$ approaches infinity, the offending firm attracts all investment dollars. As $\varrho$ goes to minus infinity, it attracts no investment dollars. At a rate $\varrho=r$, only investors who did not care or who preferred the socially incorrect policy would invest in this firm, i.e., only those with $h \leq 0$.

The firm's demand for funds is given by

$$
q_{d}=q_{d}(\varrho, a)
$$

where $a$ is a shifter in the demand function.

The equilibrium price is determined by equating supply and demand and solving for $\varrho$ :

$$
J F(\varrho-r)-q_{d}(\varrho, a)=0
$$

The standard comparative statics apply. First, differentiating along (12), we obtain

$$
\frac{d \varrho}{d a}=\frac{\frac{\partial q_{d}}{\partial a}}{J f(\varrho-r)-\frac{\partial q_{s}}{\partial \varrho}}
$$

The numerator and denominator are positive so an increase in $a$ increases the cost of funds to the firm. The larger the amount desired, the larger the rate of return that must be offered. Now suppose that $98 \%$ of the investment dollars are willing to forgo some return to avoid 
supporting the socially incorrect firm. The other $2 \%$ either do not care or prefer that firm. If the investment dollars desired by the firm accounted for $1 \%$ of the total funds in the economy, then the firm might end up paying a return lower than $r$. Since it is the marginal investor, not the average investor, who determines the rate paid, and since the marginal investor prefers the politically incorrect firm $(\mathrm{h}<0)$, the equilibrium rate of $\varrho$ is below $r$. This is shown in figure 3. If the demand for funds lies below $q_{0}$, the equilibrium rate paid will be below $r$.

A pension fund that calls attention to a firm's behavior may thus lower the cost of funds to the firm. Before notoriety, the firm had neither supporters nor detractors. It merely paid $r$ to raise capital. After the pension fund (or other investor) makes an issue of the firm's behavior, most may turn against it. But some small minority may turn in its favor and it will be the small minority that affects the equilibrium rate. Even in the case where the premium is positive, if a large proportion of the population has similar distaste for the practices of the firm, then the firm can expand its demand for funds with little effect on the rate paid. The equilibrium rate does not alter much because similar tastes produce an elastic section of the supply curve over a large range of quantities.

Now alter the assumption that the pension fund cannot affect the behavior of a firm that it purchases. A fund will attempt to modify the behavior of a firm if members of the fund get positive utility from modifying behavior. In the prior analysis, $h$ reflected negative utility associated with holding the stock of a socially bad firm. But this negative utility can be avoided by not holding the firm's stock. To justify intervention, the pension fund members must derive positive utility from changing the behavior of the irresponsible firm. If they receive positive utility, then changing the behavior of the firm is a good which will command a positive price. 
Now think of $h$ as a measure of the value of changing the behavior of the firm. Since it provides positive utility, an investment dollar must receive a rate of return $\varrho>r-h$ to change the behavior of a firm. Suppose that adopting the socially correct position reduces the firm's rate of return by c. If the firm is earning return $\varrho_{0}$ initially while engaging in irresponsible behavior, then $\mathrm{J}\left[1-\mathrm{F}\left(\mathrm{r}+\mathrm{c}-\varrho_{0}\right)\right]$ investment dollars are willing to come in and bear cost $\mathrm{c}$ to change the behavior of the firm. Let $\mathrm{K}$ be the number of dollars of equity shares. If

$$
\text { (14) } \frac{J\left[1-F\left(r+c-\varrho_{0}\right)\right]}{K}>\frac{1}{2}
$$

then the strategy to take over the firm and change its behavior will prevail. If (14) is not met, a pension fund will not purchase stock in the firm in hopes of taking it over. Obviously, nothing requires that any one fund have enough shares to bring about the change. The condition in (14) refers to the sum of shares that are willing to vote their conscience at a cost of $c$.

Condition (14) has some implications.

1. A politically oriented fund which wants to change behavior is less likely to get involved in firms with high c. If the firm will suffer large losses because of the change in policy, the pension fund might stay out altogether.

2. For a given amount of utility associated with a change, a small firm is more likely to be manipulated than a large one. As $\mathrm{K}$ falls, the chances that condition (14) will be met rises.

3. Highly levered firms are more likely to face a political agenda. Leverage reduces the number of dollar voting shares $\mathrm{K}$ relative to the scale of operations. Unless debt can control 
the firm through its lending contract, a fund will find it easier to influence a highly levered firm.

4. Increased variance in tastes increases the probability of instituting an external political agenda. Only a few individuals committed to change are needed. When a few derive a large amount of positive utility from changing the behavior of a firm, condition (14) is more likely to be met. A fat-tailed distribution is more likely to bring this condition about. Again, it is the marginal investment dollar rather than the average one that determines policy. As a result, a small number of members on the extreme fringe can bring about the change. The more variance in the distribution of taste, the more likely that there will be an extreme fringe.

\section{Conclusion}

Workers who hold a firm's stock make decisions other than those that pure capital owners would make. Workers care about their firm-specific rents and may vote to protect these rents. Because non-labor owners care only about the capital value of the firm, their decisions should be based on the total rent from the firm, including the rent that accrues to workers. But if the only penalty against firms whose decisions are biased against rents accruing to labor is a loss of reputation, and if reputation effects are slow or weak, workers may desire to own shares of the firm to protect their firm-specific rents, despite the usual argument for diversification.

Workers' views toward firm decisions will differ depending on their firm specific human capital and tenure in the firm. The workers most favorable to efficient firm decisions are the very young and very old, who have the least amount to lose in employment rent. Alliances are likely to form between very young and very old with protected workers.

Giving more shares to workers in lieu of wages can increase the number of shares that vote with non-labor owners. Workers decide how to vote by trading off the capital gains that 
they receive from making the firm more efficient against the employment rent lost by efficiency enhancing moves. As their share of ownership increases, the capital gains become more important, causing them to swing all their votes in the direction of efficiency.

When workers are owners, the appropriate severance pay policy will induce workers to vote appropriately on their own layoffs. Severance pay, with steep age-earnings profiles, is a tool that can offset some of the negative effects of labor ownership or seniority based layoff rules.

Single company based defined contribution pension funds, which hold shares in their own firm, produce uniformity in the voting of workers. This favors efficient decisions when layoffs and other changes are modest. When efficient layoff policy implies major disruption, a pension fund tends to radicalize the views of its constituent workers.

Finally, note that while pension funds that represent the interests of workers from a large number of firms are not likely to take a direct interest in any of their constituent firms, they may shun the shares of some firms or buy up and try to change the behavior of other firms. Pension funds are more likely to buy up shares and successfully change behavior in small firms, in firms that are highly levered, and when the investment community has diverse views on the benefit from changing a firm's current irresponsible policies. 


\section{References}

Bagwell, Laurie Simon, and Judd, Kenneth L. "Transaction Costs and Corporate Control" (November 1988)

Barber, Randall and Jeremy Rifkind, The North Will Rise Again: pensions, politics, and power in the 1980s (Beacon Press, Boston, 1978)

Becker, Gary S. The Economics of Discrimination. Chicago: University of Chicago Press, 1957 (2nd edition 1971).

Blasi, Joseph and Douglas Kruse The New Owners: the mass emergence of employee ownership in public companies and what it means to American Business (New York; Harper-Collins, 1991)

Blinder, Alan S. (ed) Paying for Productivity (Brookings Institution; Washington, D.C., 1990)

Borjas, George. Union Control of Pension Funds: Will the North Rise Again? (Institute for Contemporary Studies, San Francisco, 1979)

Drucker, Peter. The Unseen Revolution: how pension funds socialism came to the United States (New York: Harper and Roe, 1976)

Fischel, Daniel. "Labor Markets and Labor Law Compared with Capital Markets and Capital Law," University of Chicago Law Review 4 (1984): 1061-77.

Freeman, Richard B., and Lazear, Edward P. "An Economic Analysis of Works Councils" (May 1994), in Employee Participation and Works Councils [NBER conference volume], ed. Joel Rogers and Wolfgang Streeck, University of Chicago Press for the NBER, 1995.

Freeman, Richard B., and Weitzman, Martin L. "Bonuses and Employment in Japan," Journal of the Japanese and International Economies, Vol. I (1987): 168-194.

Hans-Bockler-Foundation Codetermination: introduction into the legal system of worker participation ub the Federal Republic of Germany (Dusseldorf, Germany, undated)

Kandel, Eugene, and Lazear, Edward P. "Peer Pressure and Partnerships, " Journal of Political Economy 100(4) (August 1992): 801-17.

Lazear, Edward P. "Pensions as Severance Pay," Financial Aspects of the U.S. Pension System, a National Bureau of Economic Research Project Report, ed. Zvi Bodie and John Shoven (Chicago: University of Chicago Press, 1984): 57-85.

Lazear, Edward P. "Why Is There Mandatory Retirement?" Joumal of Political Economy 87(6) (December 1979): 1261-84.

Mishel, Lawrence and Voos, Paula (ed) Unions and Economic Competitiveness (Washington D.C.: Economic Policy Institute, 1991) 
Murphy, Kevin J., and Van Nuys, Karen. "State Pension Funds and Shareholder Inactivism" (March 1994)

National Center for Employee Ownership, Oakland California.

Weitzman, Martin L., and Kruse, Douglas L. "Profit-Sharing and Productivity," in Paying for Productivity: A Look at the Evidence, ed. Blinder, Alan S. (Washington, D.C.: Brookings, 1990): 95-140. 

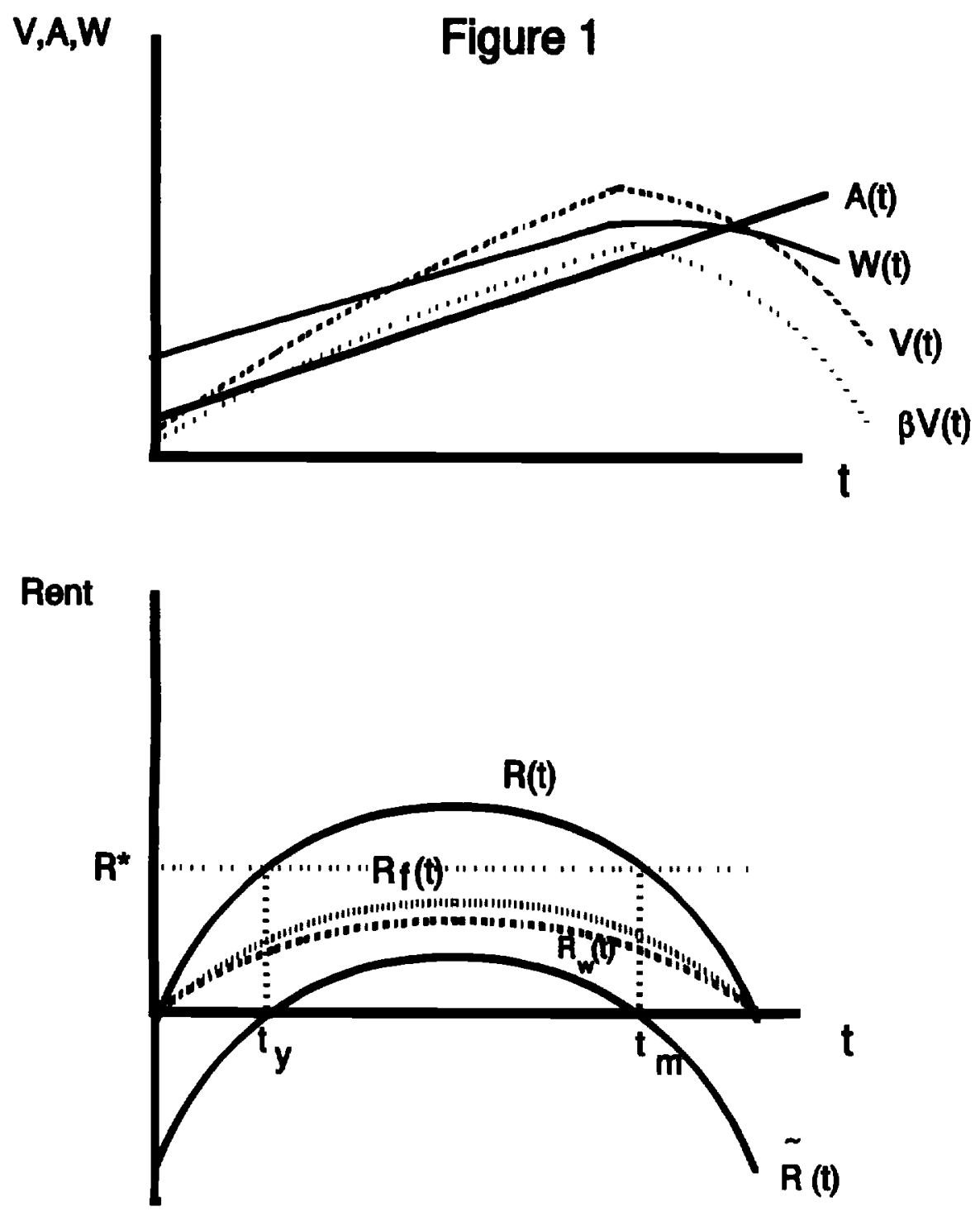

ల్ల 


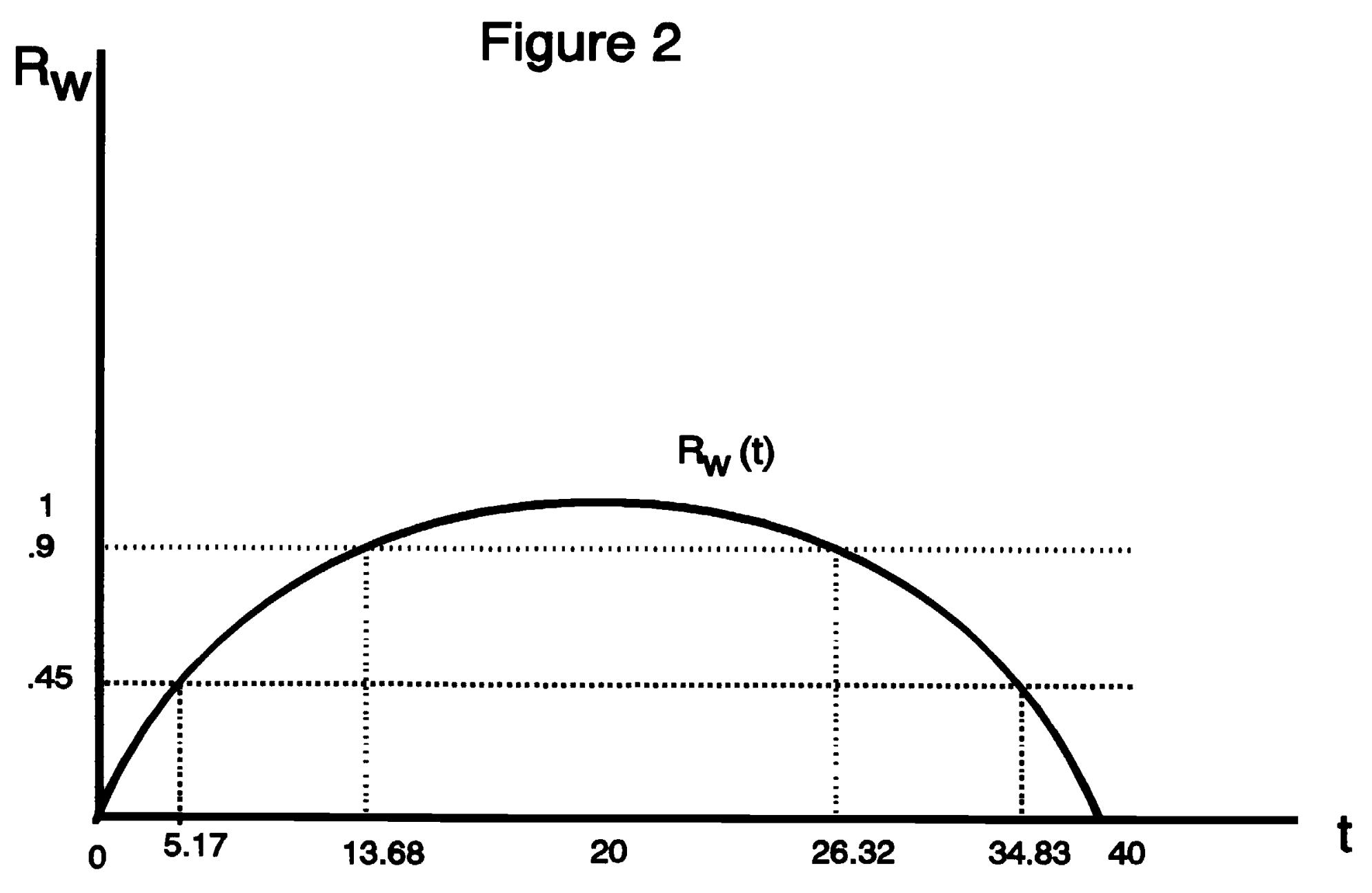




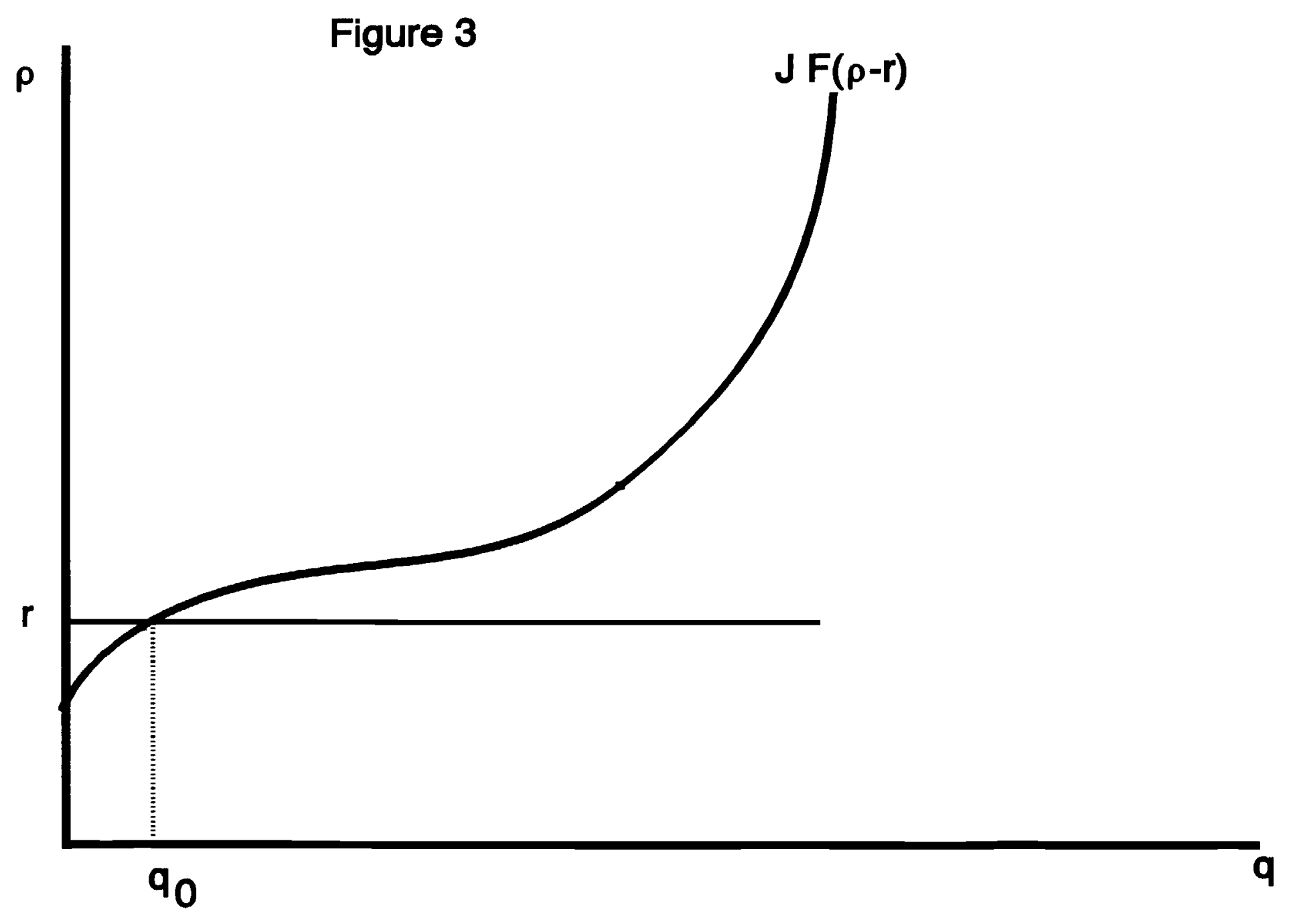


1. Japanese workers appear to receive a larger proportion of their compensation in the form of profit sharing than American workers. Freeman and Weitzman (1987). This may not be true, however, because workers wages vary implicitly with company profitability. High profit firms are high wage firms and periods of high profitability are accompanied by larger wage gains.

2. Any wage profile where wages deviate from marginal product (as in Lazear (1979)) will also cause workers to care about the firm's survival and decisions. 